\title{
Determination of the trading discount based on market data and cadastral value
}

\author{
Mikhail B. Laskin \\ Senior Researcher \\ St. Petersburg Institute for Informatics and Automation of the Russian Academy of Sciences; \\ Associate Professor, Faculty of Economics \\ St. Petersburg University \\ Address: 7-9, Universitetskaya Emb., St. Petersburg, 199034, Russia \\ E-mail: laskinmb@yahoo.com
}

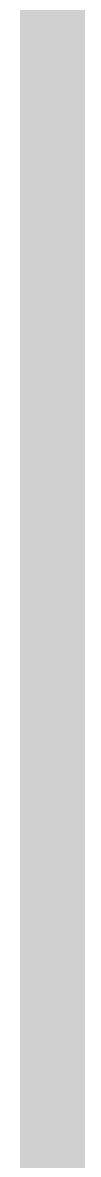

\begin{abstract}
The introduction of the institution of cadastral value in the Russian Federation opens up new opportunities in real estate valuation. In this regard, the new focus for appraisers is statistical analysis of multidimensional empirical distributions that were not previously available, because the real estate market does not have pairwise and multidimensional observations concentrated in unified databases. Data of interest to analysts is usually concentrated in different sources from different owners and pertains to different objects. The goal of combining them can be solved by comparing such data with the data of cadastral records, namely the cadastral number as a unique identifier of the object. Since the cadastral value corresponds to each cadastral number, it is possible to compare the cadastral value with important indicators such as the market price of the offer, the transaction price, the rental rate, the annual price indices, the capitalization rate, the discount rate, the trading discount and many other indicators, the formation of which involves more than two random variables. The construction of the model involves the principle of following the prices formed by pair comparisons to geometric Brownian motion, and hence the formation of lognormal population. As it turned out, as a result of large-scale cadastral work carried out in the Russian Federation in 2014, the cadastral value is also subject to lognormal distribution of prices (in each class of objects). For the market value (as the most probable price of the transaction under conditions of perfect competition), this leads to functional dependences from the cadastral value of the power type. Similarly, many other indicators will also be subject to dependences in the form of power functions. Obviously, having a function depending from the various indicators of cadastral value across the set of values, you can set the relationship between the various indicators, which was impossible before the introduction of the institution of cadastral value. This article proposes a method of calculating the trading discount when appraising real estate based on analysis of market statistics and databases of cadastral records. An analytical formula of the dependence of trading discounts from the offer price is proposed. The method allows us to set the level of the discount not only for objects included in an advertising database, but also for any object that has undergone cadastral registration.
\end{abstract}

Key words: trading discount; cadastral value; market value; stochastic pricing model; lognormal distribution of prices.

Citation: Laskin M.B. (2018) Determination of the trading discount based on market data and cadastral value. Business Informatics, no. 3 (45), pp. 53-61. DOI: 10.17323/1998-0663.2018.3.53.61. 


\section{Introduction}

I $\mathrm{n}$ the theory and practice of real estate appraising, one of the unresolved issues is determination of trading discounts. The Russian real estate market is structured in such manner that there is a lot known regarding offers to sell and very limited access (for the appraiser) to information about completed transactions with the actual sales prices. For this reason, it is very inconvenient to find statistics reflecting the offer price and the transaction price for one and the same object of real estate. In practice, appraisers often use "expert" surveys and average out the data obtained. In rising markets, the errors made are quickly compensated by dynamic changes in prices. In present-day conditions, such an approach often does not reflect the real picture.

With the introduction of the institution of cadastral inventory, new possibilities arose to establish the analytic dependence between the offer price and the transaction price, consequently to determine the trading discount.

\section{The model}

The model is based on the assumption that that bid prices and purchase prices follow lognormal distribution. Cadastral values were determined in 2014 as market values, and also followed lognormal distribution. Such a form of distribution of prices in real estate was pointed out not only by Aitchinson and Brown (the researchers of the University of Cambridge) back in 1963 [1], but also by authors of relatively recent publications [2-4]. Rusakov [5; 6] proved that prices formed by sequential comparisons under conditions of perfect competition aim at formation of lognormal distribution of the population. Market value is understood to mean the most probable price at which the object can be disposed of on the open market under conditions of perfect competition. This understanding fully corresponds to the definition of market value given in the Russian Federal Low No. 135 "About valuation activity" [7] and to foreign appraisal standards [8-11]. For one-dimensional random variables, this leads to an understanding of market value as the modal value of the respective random variable, and in cases of two-dimensional or multidimensional random variables - for the study of the most probable values of multi-dimensional random variables, for example, when studying adjustments [12], the analysis of the auction results [13], the determination of the capitalization ratio corresponding to the current market conditions [14] and other tasks in which the need to review the system of random variables arises.

Since collecting statistics containing the bid prices and purchase prices for each object is inconvenient, one can collect the statistics by the pairs "cadastral value - bid price" and "cadastral value - purchase price" then show the analytical dependences and finally show the dependence relationship of the transaction price on the offer price.

For example, if we suppose that the random variables $V_{c v}$ and $V_{o p}\left(V_{c v}\right.$ - cadastral value, $V_{o p}$ offer price) follow lognormal distribution, then given a fixed cadastral value $V_{c p}=v$ the most probable price $M V_{o p}$ (market value appraised using offer prices without consideration of trading discounts) equals:

$$
\begin{gathered}
M V_{o p}=\operatorname{Mode}\left(V_{o p} \mid V_{c v}=v\right)= \\
\exp \left(\mu_{1}+\rho_{1} \frac{\sigma_{1}}{\sigma_{2}}\left(\ln (v)-\mu_{2}\right)-\sigma_{1}^{2}\left(1-\rho_{1}^{2}\right)\right),
\end{gathered}
$$

where $\mu_{1}, \sigma_{1}$ - the parameters of lognormal distribution for the cadastral value;

$\mu_{2}, \sigma_{2}$ - the parameters of lognormal distribution for the bid prices;

$\rho_{1}-$ the correlation coefficient.

The straightforward finding of this formula is given in the works $[14 ; 15]$. We note that the formula (1) describes the dependence of market value without considering trading discounts 
from the cadastral value in the form of a power function:

$$
M V_{o p}=\operatorname{Mode}\left(V_{o p} \mid V_{c v}=v\right)=A_{1} v^{B_{1}},
$$

where $A_{1}=\exp \left(\mu_{1}-\rho_{1} \frac{\sigma_{1}}{\sigma_{2}} \mu_{2}-\sigma_{1}^{2}\left(1-\rho_{1}^{2}\right)\right)$;

$$
B_{1}=\rho_{1} \frac{\sigma_{1}}{\sigma_{2}} \text {. }
$$

A similar formula can be written as well for appraising market value using purchase prices $\left(M V_{p p}\right)$ :

$$
M V_{p p}=\operatorname{Mode}\left(V_{o p} \mid V_{c v}=v\right)=A_{2} v^{B_{2}},
$$

where $A_{2}=\exp \left(\mu_{1}-\rho_{2} \frac{\sigma_{1}}{\sigma_{3}} \mu_{3}-\sigma_{1}^{2}\left(1-\rho_{2}^{2}\right)\right)$;

$$
B_{2}=\rho_{2} \frac{\sigma_{1}}{\sigma_{3}}
$$

(here $\mu_{3}, \sigma_{3}$ is the parameters of lognormal distribution of purchase prices, $\rho_{2}$ is the correlation coefficient of the pair "cadastral value purchase price").

Then, expressing $v$ through $M V_{o p}$ (from the formula (2)) and substituting in the formula (3), we obtain the price dependence of the most likely transaction price $M V_{p p}$ from the most probable bid price $M V_{o p}$ :

$$
M V_{p p}=A_{2}\left(\frac{M V_{o p}}{A_{1}}\right)^{\frac{B_{2}}{B_{1}}} .
$$

It is obvious that this dependence also is a power function.

Let us introduce the coefficient $K$ - the ratio of the most probable purchase price to the most probable bid price. From formula (4) we see the power dependence of the coefficient $K$ from the most probable bid price:

$$
K=A_{2} A_{1}^{-\frac{B_{2}}{B_{1}}}\left(M V_{o p}\right)^{\frac{B_{2}}{B_{1}}-1} .
$$

From formula (5), it is apparent that the trading discount is not constant and given the defined parameters of the laws of distributions of bid prices, purchase prices and cadastral values can significantly change for different offer prices.

\section{Calculation example}

For our calculations, we have selected data from the Real Estate Bulletin No. 1758 (December 2016) ${ }^{1}$, data from the cadastral records of objects in the residential housing stock of St. Petersburg published in [16], on the basis of the report [17] and data from one of the St. Petersburg real estate agencies which presented on a confidential basis its data on the prices of 294 actual transactions in 2017. The information presented by the agency relates only to necessary numerical indicators and does not contain any personal data. Adjustments for time during 2017 were not made inasmuch as there were no significant changes on the market. Unfortunately, databases of an advertising nature such as the "Real Estate Bulletin" do not contain data from the cadastral records (above all, the cadastral number, as the unique identifier of the object and of its cadastral value). The community of appraisers should consider the possibility of creating databases containing not only the market information and description of the price-forming factors but also data from the cadastral records, because the cadastral number is the unique identifier of all real estate objects. If all databases contained the cadastral number (and data from the cadastral records), then it would be possible to integrate the data from various databases into one and examine the multi-dimensional random variables. For the moment, we have to apply other technique to identify the objects. In particular, for data taken from the "Real Estate Bulletin," we succeeded in identifying (establishing the cadas-

\footnotetext{
${ }^{1}$ Portal of the Bulletin of St. Petersburg Real Estate" (www.bn.ru) dated 8 December 2016, No. 1758
} 

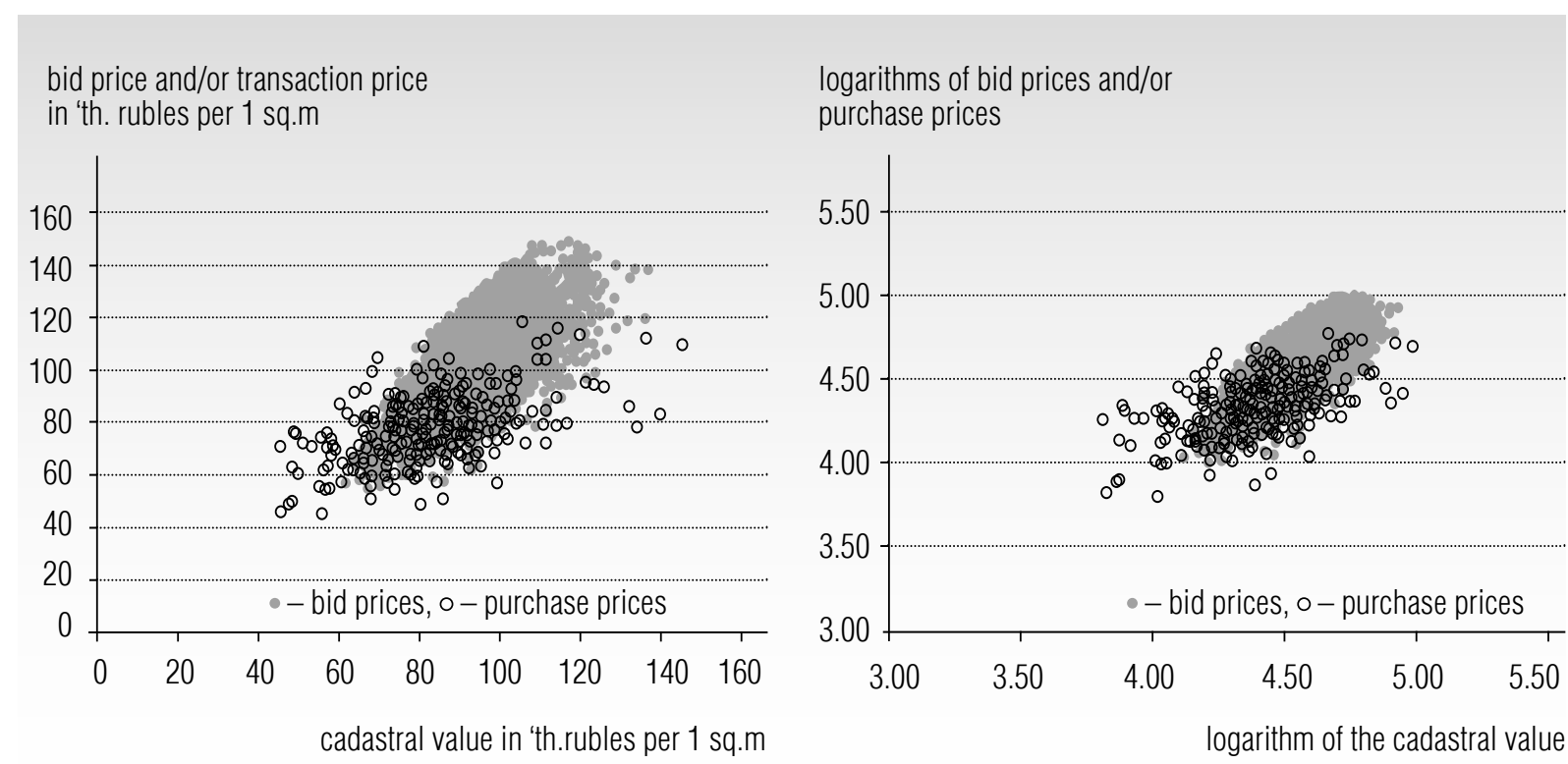

Fig. 1. Scatter-plot chart of the pairs "cadastral value - bid price"

and "cadastral value - purchase price" for secondary real estate in St. Petersburg in 2017, for the "mass market" segment in natural prices (on the left) and on the logarithmical plane (on the right)

tral number and cadastral value) of more than 2300 objects. In Figure 1 we presented the scatter-plot charts of the pairs "cadastral value bid price," "cadastral value - purchase price" for secondary real estate in St. Petersburg in 2017, for the mass-market segment (the premium segment was not examined as it is a segment requiring separate study).

Empirical distributions of bid prices, very often, do not allow us satisfactorily to approximate right away lognormal distribution. This is explained, above all, by the fact that the market data are a mixture of distributions of prices for objects of various classes. The task of separating out the mixtures belongs to the class of incorrect tasks and cannot be solved by mathematical methods only. Fortunately, in the evaluation of a property, to separate out the mixtures you always can use a set of priceforming factors, part of which is reflected in the market databases. In the given case, a satisfactory approximation was obtained after removing from the sample objects relating to the premium segment and removing an insignificant number of outliers with abnormally elevated expectations of sellers (the remaining size of the sample -2331 objects). The approximating surfaces are presented in Figure 2.

The approximating surfaces have been tested by the circular KS test $[14 ; 15]$. The results are presented in Figure 3.

In the test for the pair "cadastral value - bid price," the minimal value $p$-value comes to 0.055 ; and for the pair "cadastral value - purchase price" - the $p$-value equals 0.33 . The values obtained provide a basis for not rejecting the hypothesis of combined lognormal distribution.

When modeling, we obtained the following sample values of the parameters of combined lognormal laws of distribution. For the pair "cadastral value - bid price," $\mu_{1}=4.53$, $\sigma_{1}=0.126, \mu_{2}=4.56, \sigma_{2}=0.178, \rho_{1}=0.756$. By substituting the indicated values in the formula (2) we get: 


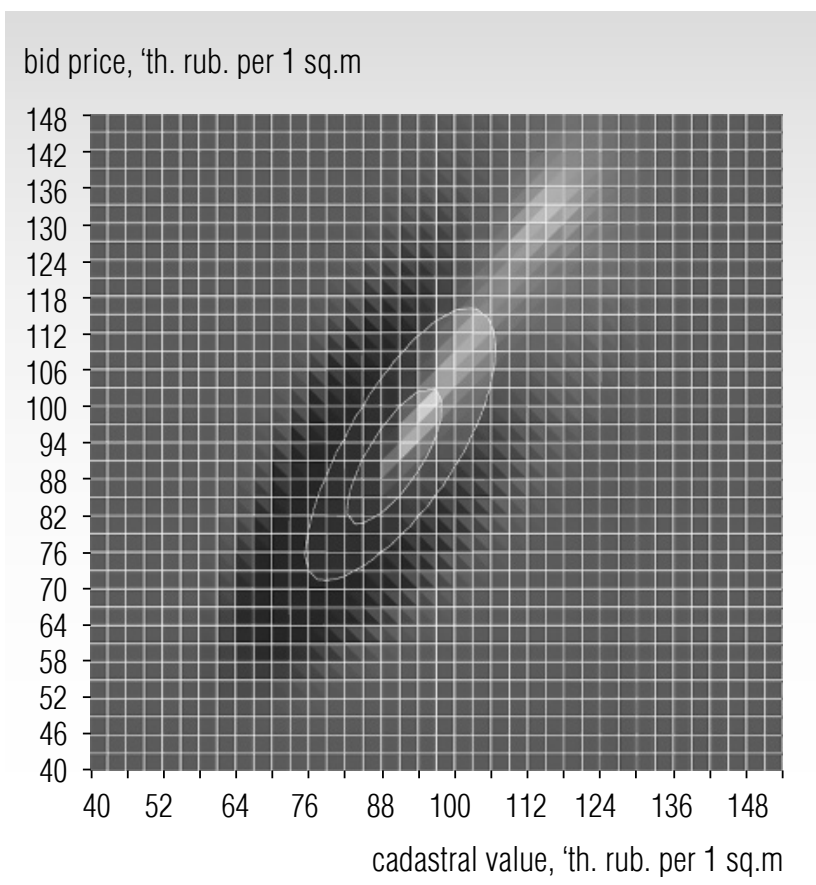

purchase price, "th. rub. per 1 sq.m

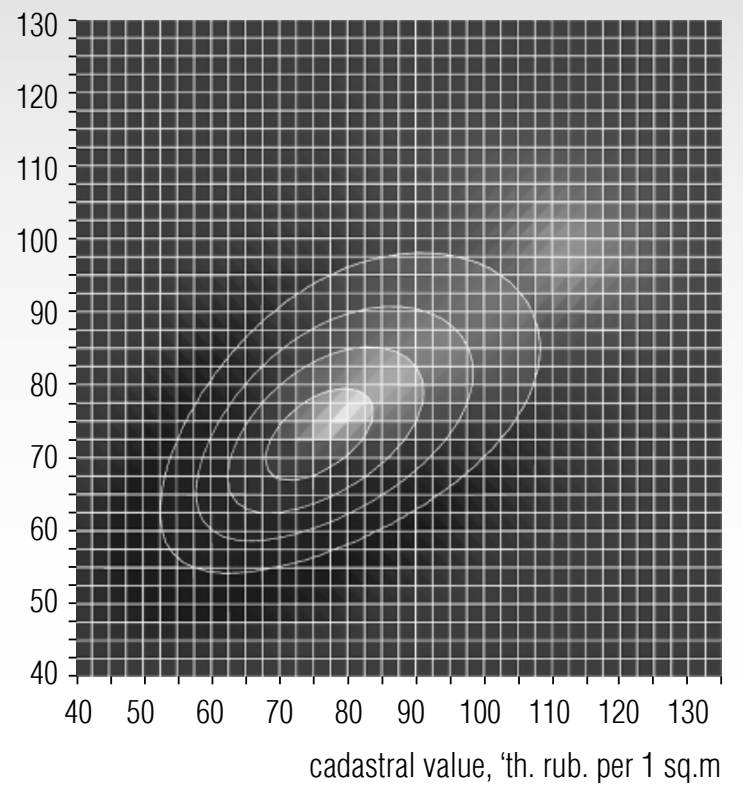

Fig. 2. Approximating surfaces of combined lognormal dstribution of the pairs "cadastral value - bid price" (left) and "cadastral value - purchase price" (right)

$$
\begin{aligned}
A_{1} & =0.758 \\
B_{1} & =1.064 \\
M V_{o p} & =0.758 v^{1.064} .
\end{aligned}
$$

For the pair "cadastral value - purchase price" $\mu_{1}=4.384, \sigma_{1}=0.207, \mu_{3}=4.337$, $\sigma_{3}=0.17, \rho_{2}=0.52$. Substituting the indicated values in the formula (3) we get:

$$
\begin{aligned}
A_{1} & =11.72 \\
B_{1} & =0.422 \\
M V_{o p} & =11.72 v^{0.422} .
\end{aligned}
$$

Both dependences are presented in Figure 4.

The dependences obtained for valuations of market value come from different statistics: for market data - on the basis of announcements of sales and for sales data, real estate agencies. These dependences are built on analysis of data from various samples. The objects from these samples are various and are in no way connected to one another except for cadastral values.
Objects having the same cadastral value are not necessarily placed on sale and sold for the same price. However, if when determining the cadastral value the following principle is observed "cadastral value is determined as the market value obtained by the methods of mass evaluation on the date of appraisal" - then the appraiser has the right, when constructing his valuation, to proceed from the assumption that two such objects have roughly the same market value. Furthermore, since the cadastral value is established for the purposes of taxation, the principle of social justice presupposes that for objects with identical market value the owners should pay the same taxes. That is precisely why the task of periodic review of cadastral value arises.

In our case, cadastral value also acts as the instrument for highlighting the dependence between the bid price and the purchase price (or between the bid price and the multiplier coefficient determining the trading discount). By substituting the values of the coefficients (6) and (7) in the formulas (4) and (5), we get: 

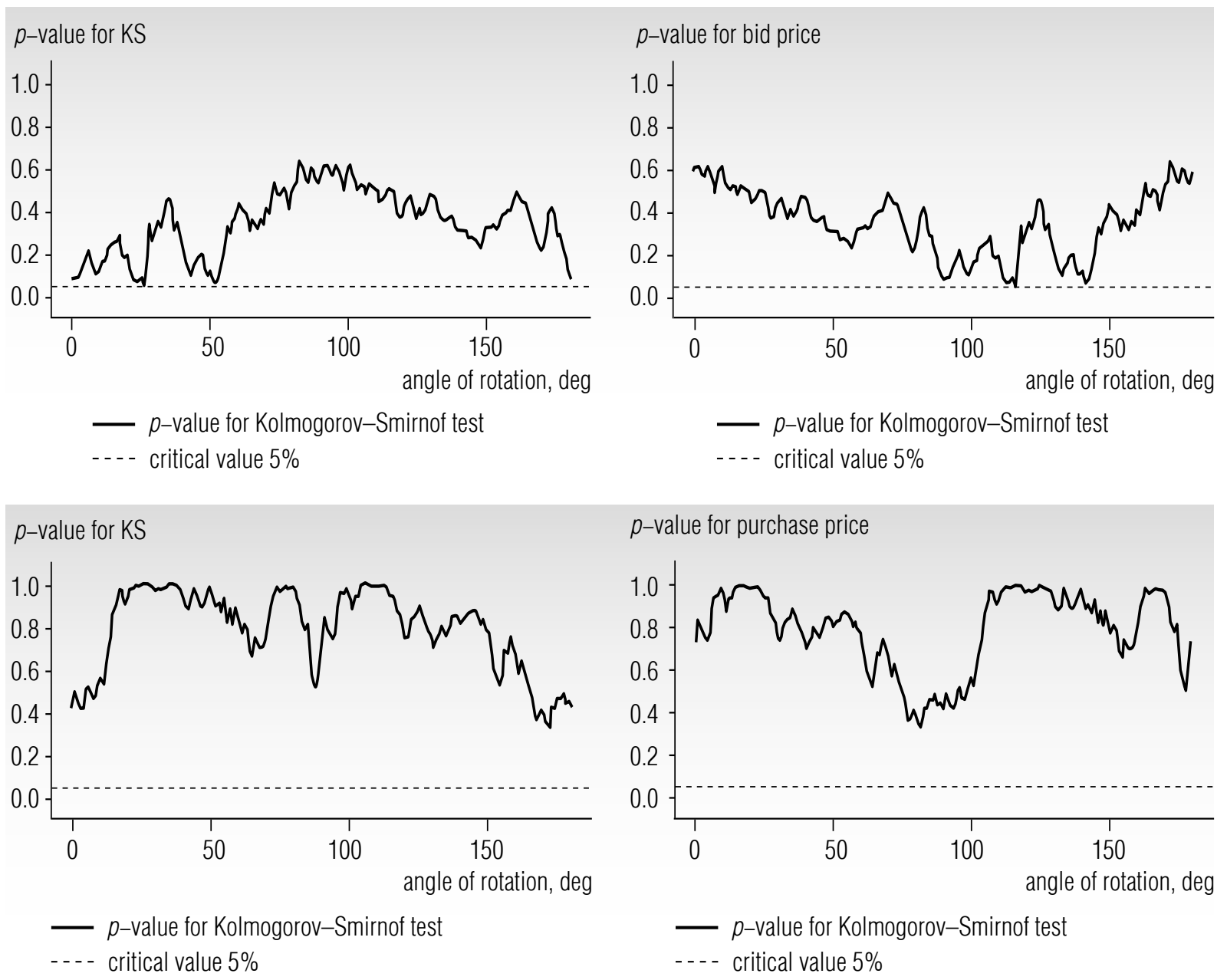

Fig. 3. Results of the circular KS test for the pair "cadastral value - bid price" (upper row) and for the pair "cadastral value - purchase price" (lower row)

$$
\begin{gathered}
M V_{p p}=13.08 M V_{o p}^{0.396} \\
K=13.08 M V_{o p}{ }^{-0.604}
\end{gathered}
$$

Both dependences are presented in Figure 5.

The dependence indicated in the right chart of Figure 5 de facto describes the valuation of the trading discount in the sector of secondary real estate in St. Petersburg in 2017. As we see, the valuation of the trading discount is not constant. For the sector of secondary residential real estate in the mass-market segment, at a bid price of 140,000 rubles/ sq.m. it can amount to $35 \%$. In addition, this same line shows that a bid price below
70,000 rubles/sq,m. should be applied with caution. For example, a bid price of 60,000 rubles/sq.m. lags behind the most probable sale price by $10 \%$ (approximately 66,000 rubles/sq.m.). However, this does not mean that the seller, having received such information, must immediately set a price as much higher as possible. Most sellers proceed from rational considerations, weighing the time for showing on the market with their own need for cash and with their wish to sell the object more expensively. Basically such information is needed by the community of appraisers to make a justified selection of trading discount when appraising objects of real estate. 


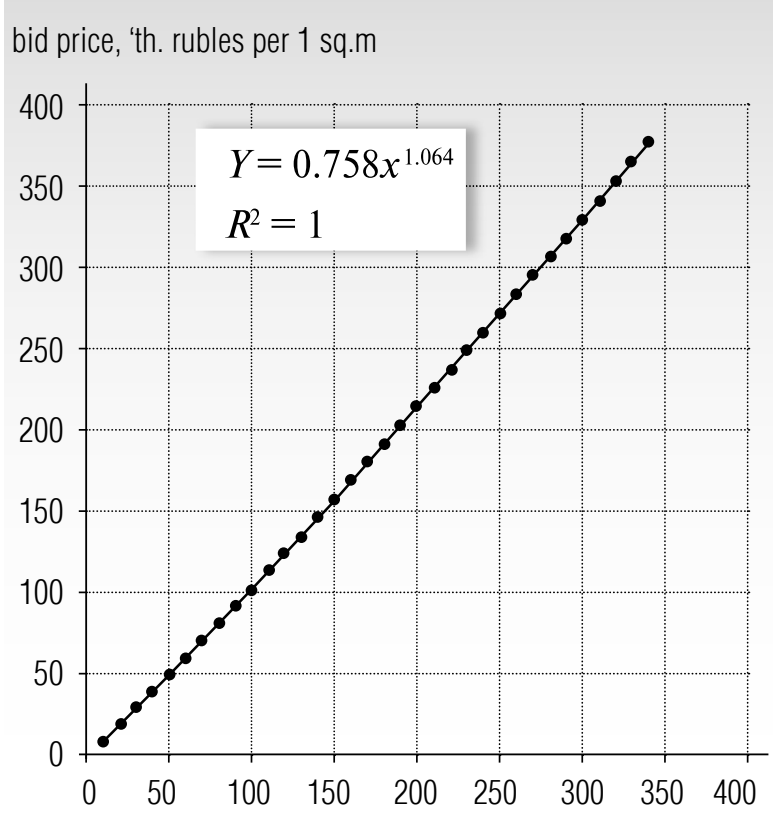

purchase price, 'th. rubles per 1 sq.m

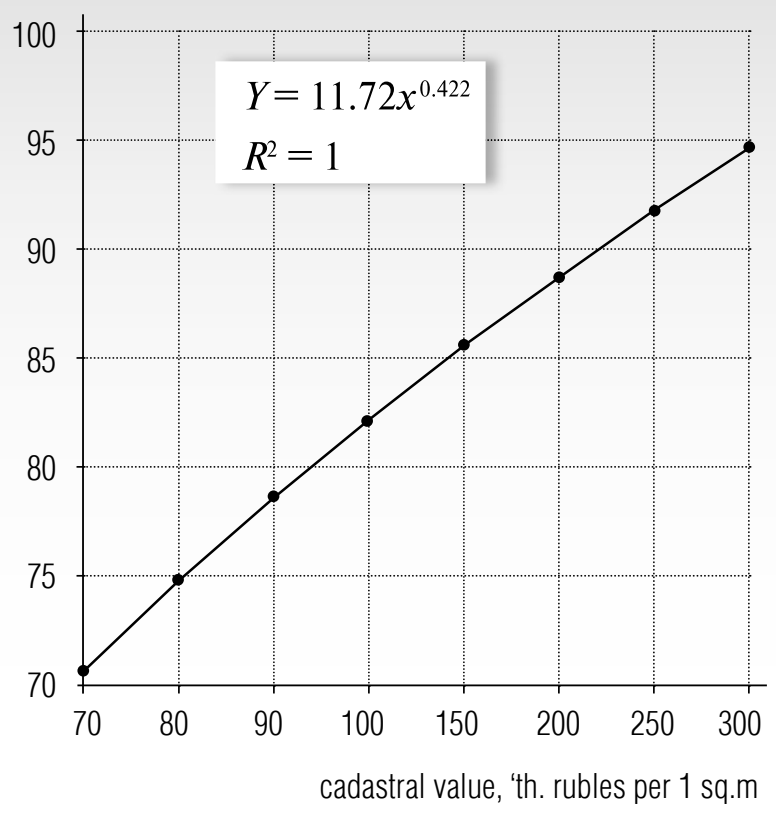

Fig. 4. The dependences of market value determined via bid prices from cadastral value (left)

and market value obtained via purchase prices from cadastral value (right)

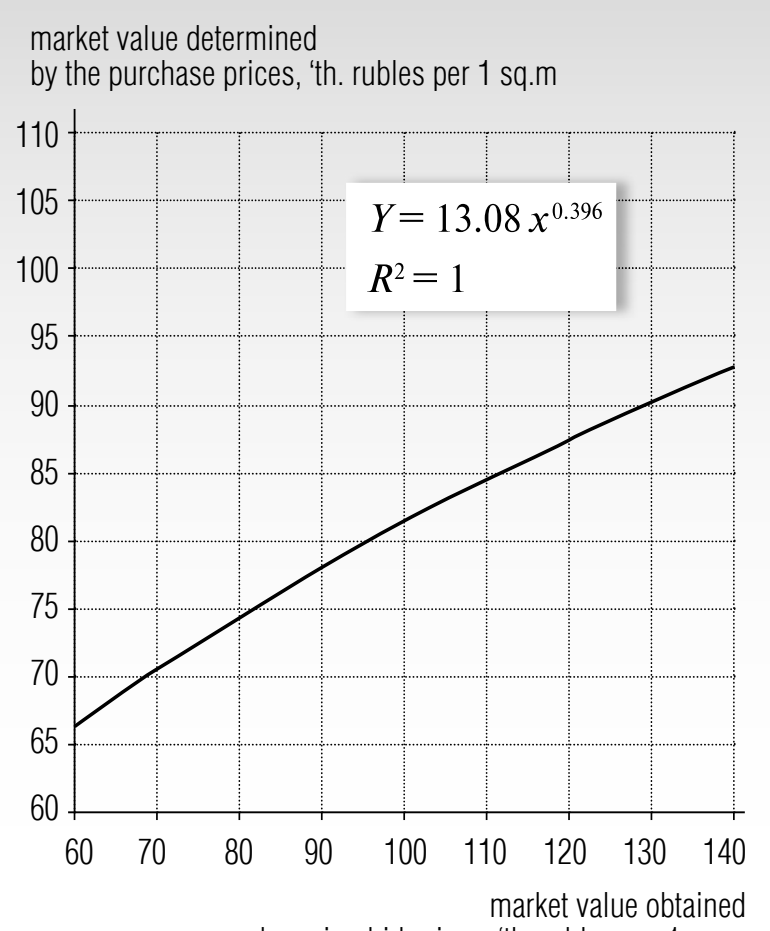

by using bid prices, 'th. rubles per 1 sq.m multiplier coefficient

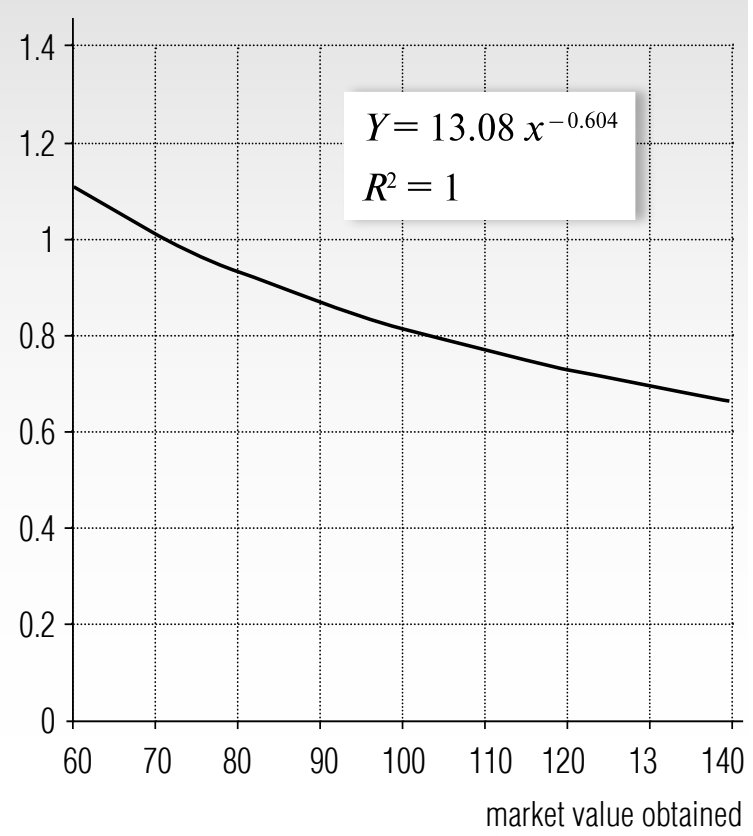

by using bid prices, 'th. rubles per 1 sq.m

Fig. 5. The dependence of valuation of market value determined by the purchase prices from the valuation of market value obtained by using bid prices (left) and the dependence of the multiplier coefficient from the bid price (right) 


\section{Conclusion}

The creation of the institution of cadastral value in the Russian Federation opens new, previously inaccessible methods of analyzing the real estate market and evaluating market figures, in particular, determination of the trading discount.

Cadastral value determined as the market value on the date of appraisal prior to the date of its regular review is an important analytical tool, and not just the basis for calculating the property tax.
The proposed approach (juxtaposition of bid prices and purchase prices with the cadastral value determined by methods of mass evaluation as market value on the date of appraisal) can be applied also when adjusting cadastral value. We examine this question in detail in the recently published article [18], which we were prompted to write following the lively discussion in the community of appraisers over the quality of determination of cadastral value. A detailed analysis of the methodological problems of determining cadastral value can be found in the article of Professor Korostelev [19]

\section{References}

1. Aitchinson J., Brown J.A.C. (1963) The lognormal distribution with special references to its uses in economics. Cambridge, Cambridge University Press.

2. Ciurlia P., Gheno A. (2009) A model for pricing real estate derivatives with stochastic interest rates. Mathematical and Computer Modeling, no. 50, pp. 233-247.

3. Ohnishi T., Mizuno T., Shimizu C., Watanabe T. (2011) On the evolution of the house price distribution. Columbia Business School. Center of Japanese Economy and Business. Working Paper Series, no. 296.

4. Nikulina T.V., Ponomareva O.A., Popentzova S.V. (2015) Logarifmicheski normal'noe raspredelenie tsen na zhilye ob'ekty nedvizhimosti elitnogo klassa i ekonom-klassa [Lognormal distribution of prices for residential real estate of elite class and economy class]. Week of science of SPbSPU. Materials of the scientific forum with international participation (ed. O.V. Kalinina, S.V. Shirokova). Saint Petersburg, pp. 435-437 (in Russian).

5. Rusakov O.V., Laskin M.B., Jaksumbaeva O.I. (2016) Stokhasticheskaya model' tsenoobrazovaniya na rynke nedvizhimosti: formirovanie lognormal'noy general'noy sovokupnosti [Stochastic pricing model for the real estate market. Formation of lognormal general population]. Economics, Statistics and Informatics. UMO Bulletin, no. 5, pp. 116-127 (in Russian).

6. Rusakov O.V., Laskin M.B., Jaksumbaeva O.I. (2016) Pricing in the real estate market as a stochastic limit. Log Normal approximation. International Journal of Mathematical Models and Methods in Applied Sciences, vol. 10, pp. 229-236.

7. The Federal Law of 29.07.1998 No. 135-FZ (edition of 29.07.2017) "Ob otsenochnoy deyatel'nosti v Rossiyskoy Federatsii" ["About valuation activity in the Russian Federation"]. Available at: http://www.consultant.ru/document/cons_doc_LAW_19586/(accessed 01 June 2018) (in Russian).

8. The European Group of Valuers' Associations (2012) European valuation standards 2012. Available at: https://ru.scribd.com/document/254068172/Valuation-Standards-2012-for-European-Countries (accessed 01 June 2018).

9. International Valuation Standard Council (2013) International valuation standards 2013. Framework and requirements. Available at: http://www.valuersinstitute.com.au/docs/professional_practice/ International\%20Valuation\%20Standards\%202013.pdf (accessed 01 June 2018).

10. Royal Institution of Chartered Surveyors (2014) RICS valuation professional standard 2014. Available at: http://hoadd.noordhoff.nl/sites/7605/_assets/7605d24.pdf (accessed 01 June 2018).

11. The Appraisal Foundation (2018) Uniform standards of professional appraisal practice. 2018-2019 edition. Available at: http://www.uspap.org/ (accessed 01 June 2018).

12. Laskin M.B. (2017) Korrektirovka rynochnoy stoimosti po tsenoobrazuyushchemu faktoru "ploshchad' ob'ekta" [Market value adjustment for the pricing factor "square"]. Property Relations in the Russian Federation, no. 8 (191), pp. 86-99 (in Russian). 
13. Laskin M.B. (2018) Statisticheskiy analiz rezul'tatov torgov. Interval startovoy tseny [Statistical analysis of the auction results. Starting price interval]. Property Relations in the Russian Federation, no. 1 (196), pp. 19-29 (in Russian).

14. Rusakov O.V., Laskin M.B., Jaksumbaeva O.I. (2016) Opredelenie koeffitsienta kapitalizatsii po statisticheskim dannym [Determination of capitalization coefficient using statistical data]. Economics, Statistics and Informatics. UMO Bulletin, no. 1, pp. 14-22 (in Russian).

15. Rusakov O.V., Laskin M.B., Jaksumbaeva O.I. (2016) Otsenka pokazateley rynka nedvizhimosti po statisticheskim dannym na osnove mnogomernogo logarifmicheski normal'nogo zakona [Estimation of the real estate market indexes according to statistical data and based on multidimensional log-normal distribution]. HSE Economic Journal, vol. 20, no. 2, pp. 268-284 (in Russian).

16. St. Petersburg Committee of Property Relations (2015) On approval of the results of the cadastral value of the premises with the area less than 3,000 sq $\mathrm{m}$ on the territory of St. Petersburg. The order of the St. Petersburg Committee of Property Relations, 27 August 2015, no. 59-p.

17. Government of St. Petersburg (2012) The report on determination of cadastral value of real estate objects (except for the parcels of land) located in the territory of St. Petersburg, vol. 2, section 2.3.

18. Laskin M.B., Gadasina L.V. (2018) Kak opredelit' kadastrovuyu stoimost' [How to determine cadastral value]. Property Relations in the Russian Federation, no. 3, pp. 42-53 (in Russian).

19. Korostelev S.P. (2017) O “edinoy federal'noy metodologii" kadastrovoy otsenki nedvizhimosti i zemli [On the "uniform Federal methodology" of cadastral valuation of real estate and land]. Available at: http://www.labrate.ru/articles/2017-1_korostelev.pdf (accessed 28 May 2017) (in Russian). 